\title{
CHARACTERISTICS OF THE CORONARY ARTERIAL LESIONS IN YOUNG PATIENTS WITH ACUTE MYOCARDIAL INFARCTION
}

\author{
Lubna Noor ${ }^{\boxplus}$, Yasir Adnan ${ }^{2}$, Muhammad Habeel Dar ${ }^{3}$, \\ Umair Ali ${ }^{4}$, Farooq Ahmad ${ }^{5}$, Zahid Aslam Awan ${ }^{6}$
}

\begin{abstract}
OBJECTIVES: To assess characteristics of coronary arterial lesion (CAL) by means of invasive coronary angiography in young patients, aged $<35$ years, who sustained acute myocardial infarction (AMI).

METHODS: This prospective study of one-year duration was conducted from December 2009 to November 2010 at the cardiology departments of three teaching hospitals in Peshawar, Pakistan. All patients aged $<35$ years, evaluated angiographically after an AMI, were included. The individual CAL were characterized.
\end{abstract}

RESULTS: About I0I patients with AMI underwent coronary angiography. Mean age of the patients was 32.56 \pm 3.26 years (range 22-35 years). Out of $10 \mathrm{I}$ patients, $86(78.18 \%)$ were males, while 15 (21.81\%) were females. On coronary angiography, there were 25 (24.8\%) patients with nonatherosclerotic coronary arteries, 39 (38.6\%) with single vessel disease (SVD), 18 (17.8\%) had double vessel disease (DVD), and 19 (18.8\%) had triple vessel disease (TVD). Of the total, 3 patients $(2.97 \%)$ had disease in the left main stem. One hundred thirty-two lesions $(39 \times 1=39$ in SVD; $18 \times 2=36$ in DVD \& $19 \times 3=57$ in TVD) were studied. The lesions were mostly discrete to tubular with less diffuse involvement and had either no or mild calcification. Thrombus was found in 5 patients with SVD (I2.82\%), 2 with DVD (II.I I\%) and I with $\operatorname{TVD}(1.75 \%)$.

CONCLUSION: This study showed that young (age $<35$ years) patients who have sustained $\mathrm{AMI}$, have less extensive coronary artery disease but complex morphologic features. There was a higher incidence of normal vessels on coronary angiography with a very few cases of left main coronary arterial involvement.

KEY WORDS: Myocardial Infarction (MeSH); Coronary Artery Disease $(\mathrm{MeSH})$; Coronary arterial lesions (Non-MeSH); Coronary Angiography (MeSH), Atherosclerosis (MeSH).

THIS ARTICLE MAY BE CITED AS: Noor L, Adnan Y, Dar MH, Ali U, Ahmad F, Awan ZA. Characteristics of the coronary arterial lesions in young patients with acute myocardial infarction. Khyber Med Univ J 20I8;10(2):8I-85.

\section{INTRODUCTION}

7

he prevalence of acute myocardial infarction (AMI) in the young age groups has increased.' Additionally; $\mathrm{MI}$ in very young patients aged $\leq 35$ years has been poorly studied. Young patients aged $\leq 35$ years constitute less than $2 \%$ of all AMls. ${ }^{2}$ Previous studies suggested that Asians are at an increased risk of myocardial infarction at a younger age ( $<40$ years), irrespective of whether they have migrated to other countries or are resident Asians. ${ }^{3}$ Heart diseases are rising in Asian Indians and present 5-10 years earlier than in other populations around the world. ${ }^{4}$

The prevalence of risk factors has been rising in young adults. This will result in an increased disease burden in the near future. Smoking, which has been traditionally recognized as the most common risk factor for heart disease, has been shown to be increasingly prevalent in young adults and
$1^{凶}$ Assistant Professor Cardiology, Lady Reading Hospital, Peshawar, Pakistan Email:drlubnanoor@gmail.com

2 Senior Registrar Cardiology, Rehman Medical Institute, Peshawar, Pakistan

3 Cardiologist, Moulvee Ameer Shah Hospital, Peshawar, Pakistan

4 Cardiologist, Moulvee Ameer Shah Hospital, Peshawar, Pakistan

5 Assistant Professor, Khyber Teaching Hospital, Peshawar, Pakistan

6 Professor of Cardiology, Hayatabad Medical Complex Peshawar, Pakistan

Date Submitted: April 04, 2017

Date Revised: February 18,2018

Date Accepted: March 12, 2018

adolescents reaching up to $9 \% .{ }^{5}$ Obesity is a growing concern among young adults and children and it has increased three folds in the UK in the past two decades. ${ }^{5-10}$ The disproportionate rise in prevalence of heart disease among certain ethnic groups like people of Asian Indian origin has been of great interest and these people tend to get $\mathrm{Ml}$ at a younger age in addition to more complex coronary artery abnormalities. ${ }^{5-7}$

Notably, young patients are at increased risk to be misdiagnosed since they do not frequently have traditional coronary risk factors. ${ }^{11-12}$ Angiographic studies also showed major differences with higher incidence of normal coronary arteries, mild luminal irregularities, and single vessel coronary artery disease. ${ }^{13}$

There is limited data available concerning the risk factors, clinical features and characterization of coronary arterial lesions by coronary angiography on very young adults with acute myocardial infarction in Pakistan. So, this study was conducted to assess characteristics of coronary arterial lesion (CAL) by means of invasive coronary angiography in young patients, aged $<35$ years, who sustained AMI.

\section{METHODS}

Between December 01 ${ }^{\text {st }}, 2009$ and November $30^{\text {th }}, 2010$, a total of 132 patients were entered into the registry. These patients were collected from the cardiology departments of the 3 main teaching hospitals in public sector in Peshawar, Pakistan, namely Hayatabad Medical Complex (Peshawar), Lady Reading Hospital (Peshawar) and Khyber Teaching Hospital (Peshawar). 


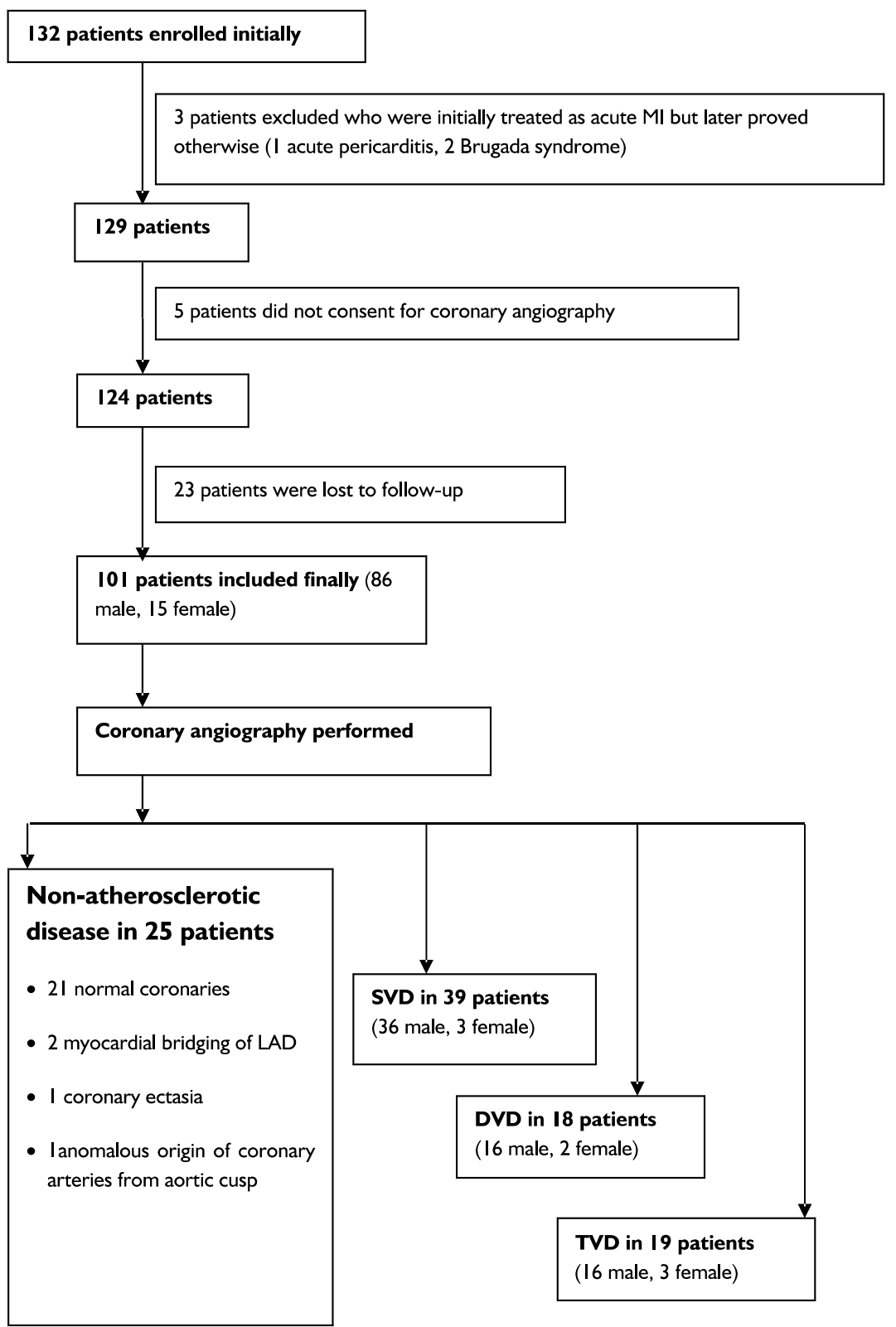

Figure I: Algorithm of the Study

Initially I 32 patients who have had a history of myocardial infarction at presentation were included in the study. Acute Myocardial Infarction was diagnosed according to standard criteria defined in guidelines. Three patients were excluded from the study who were initially diagnosed and treated as acute MI, but later two of these turned out to be Brugada Syndrome and one acute pericarditis. Also, demographic data e.g. name, age, gender, address etc. were recorded on the proforma annexed. Patients were counseled and proforma annexed. Data was analyzed by SPSS software version 16 .

\section{RESULTS}

A total of 101 patients with acute myocardial infarction underwent coronary angiography. Mean age of the patients was 32.56 \pm 3.26 years (range 22-35 years). Eighty-six patients (78.18\%) were male, while I5 (2I.8I\%) were female. As revealed by the coronary angiography, there were 25 (24.8\%) patients with non-atherosclerotic coronary arteries, 39 (38.6\%) with single vessel disease (SVD), 18 patients $(17.8 \%)$ had double vessel disease (DVD) and 19 patients (I8.8\%) had triple vessel disease (TVD) (Figure I). Of the total, 3 patients $(2.97 \%)$ had disease in the left main stem.

Left anterior descending (LAD) was found to be most frequently involved in all patterns of coronary artery disease (CAD), whether SVD, DVD or TVD. A total of 63 lesions $(46.66 \%)$ occurred in LAD, followed by 35 lesions ( $25.92 \%)$ in right coronary artery (RCA), 32 $(23.70 \%)$ in left circumflex, $3(2.22 \%)$ in left main stem (LMS), and 2 lesions (I.48\%) in Ramus Intermedius. One hundred thirty-two lesions $(39 \times 1=39$ in SVD; $18 \times 2=36$ in DVD \& $19 \times 3=57$ in TVD) were studied and characterized according to The American College of Cardiology and American Heart Association (ACC/AHA) coronary artery lesion classification system ${ }^{14}$ (Table I).

\section{DISCUSSION}

In our study, we found a relatively high frequency of angiographically normal coronary arteries, almost one fourth of the total study population. This important finding of our study conforms to the high incidence of angiographically normal coronary arteries in young patients with $\mathrm{AMI}$, a fact which has been recorded previously as well. ${ }^{15-17}$

There is paucity of data in literature regarding the characteristics of angiographic stenosis morphologic features in young patients who sustain acute myocardial infarction. A study by Chen et $\mathrm{al}^{18}$ in UK in 1995 is worth mentioning. In our study, we observed that there was a dominance of normal coronaries and SVD, and complex 
TABLE I: CHARACTERISTICS OF THE CORONARY ARTERIAL LESIONS

\begin{tabular}{|c|c|c|c|c|c|}
\hline \multicolumn{3}{|c|}{$\begin{array}{l}\text { "Lesions in } 39 \text { SVD }(39 \times 1=39):{ }^{* *} \text { Lesions in I8 DVD }(18 \times 2=36) ; \\
{ }^{* * *} \text { Lesions in 19 TVD }(19 \times 3=57)\end{array}$} & $\begin{array}{l}\text { Single Vessel } \\
\text { Disease (SVD) }\end{array}$ & $\begin{array}{l}\text { Double Vessel } \\
\text { Disease (DVD) }\end{array}$ & $\begin{array}{l}\text { Triple Vessel } \\
\text { Disease (TVD) }\end{array}$ \\
\hline \multirow{3}{*}{$\begin{array}{l}\text { Total Number } \\
\text { of Lesions }\end{array}$} & \multicolumn{2}{|c|}{ Number of patients } & 39 & 18 & 19 \\
\hline & \multicolumn{2}{|c|}{ Number of lesions } & $39 \times 1=39$ & $18 \times 2=36$ & $19 \times 3=57$ \\
\hline & \multicolumn{2}{|c|}{ Lesion Characteristics } & SVD (\%) & DVD (\%) & TVD (\%) \\
\hline \multirow{4}{*}{ SITE } & \multicolumn{2}{|l|}{ Ostial } & $02(5.12)$ & $08(22.22)$ & $08(14.03)$ \\
\hline & \multicolumn{2}{|c|}{ Proximal } & $25(64.10)$ & $19(52.77)$ & $18(31.57)$ \\
\hline & \multicolumn{2}{|l|}{ Mid } & II (28.20) & $07(19.44)$ & $22(38.59)$ \\
\hline & \multicolumn{2}{|l|}{ Distal } & 이 (2.56) & $02(5.55)$ & $09(I 5.78)$ \\
\hline \multirow{2}{*}{ EDGES } & \multicolumn{2}{|c|}{ Concentric } & $20(51.28)$ & $22(6 I .1 I)$ & $32(56.14)$ \\
\hline & \multicolumn{2}{|c|}{ Eccentric } & $10(25.64)$ & $10(27.77)$ & $12(21.05)$ \\
\hline & \multicolumn{2}{|c|}{ Regular } & $22(56.4 I)$ & $26(72.22)$ & $29(50.87)$ \\
\hline & \multicolumn{2}{|c|}{ Ulceration } & $06(15.38)$ & $04(\mathrm{II} . \mathrm{II})$ & $12(21.05)$ \\
\hline SURFACES & \multicolumn{2}{|c|}{ Intimal flap } & 이 (2.56) & 00 & 00 \\
\hline & \multicolumn{2}{|c|}{ Aneurysm } & 00 & 00 & 00 \\
\hline & \multicolumn{2}{|c|}{ Saw-toothed appearance } & $02(5.12)$ & $02(5.55)$ & $(5.26)$ \\
\hline & \multicolumn{2}{|c|}{ Simple } & $25(64.10)$ & $15(4 I .66)$ & $31(54.38)$ \\
\hline LOCATION & \multicolumn{2}{|c|}{ Bifurcation } & $15(38.46)$ & $05(13.88)$ & $17(29.82)$ \\
\hline & \multicolumn{2}{|c|}{ Trifurcation } & 00 & $02(5.55)$ & $05(8.77)$ \\
\hline \multirow{4}{*}{ CALCIFICATION } & \multicolumn{2}{|c|}{ None } & $21(53.84)$ & $13(36.11)$ & $20(35.08)$ \\
\hline & \multicolumn{2}{|l|}{ Mild } & $06(15.38)$ & $18(50.00)$ & $23(40.35)$ \\
\hline & \multicolumn{2}{|c|}{ Moderate } & $04(10.25)$ & 이 (2.77) & $01(1.75)$ \\
\hline & \multicolumn{2}{|c|}{ Severe } & 00 & 00 & 00 \\
\hline & Discrete & & $13(33.33)$ & I5 (4I.66) & $13(22.80)$ \\
\hline LENGTH & Tubular & & $14(35.89)$ & $10(27.77)$ & $13(22.80)$ \\
\hline & Diffuse & & $04(10.250$ & 07 (19.44) & $18(31.57)$ \\
\hline & Total & & $09(23.07)$ & 04 (II.II) & $14(24.56)$ \\
\hline & Severe & & $23(58.97)$ & $22(6 I .1 I)$ & $4 I(7 I .92)$ \\
\hline OCCLUSION & Moderat & & $03(7.69)$ & $10(27.77)$ & $01(\mathrm{I} .75)$ \\
\hline & Mild & & 이 (2.56) & 00 & 00 \\
\hline & Re-canal & & $03(7.69)$ & 00 & 00 \\
\hline & Grade 3 & & $15(38.46)$ & $10(27.77)$ & $05(8.77)$ \\
\hline TIMI FIOW GRADF & Grade 2 & & $12(30.76)$ & $19(52.77)$ & $26(45.6 I)$ \\
\hline TIMI FLU W GKADE & Grade I & & $03(7.69)$ & $03(8.33)$ & $12(21.05)$ \\
\hline & Grade 0 & & $09(23.07)$ & $04(\mathrm{II} . \mathrm{II})$ & $14(24.56)$ \\
\hline THROMBUS & Present & & 05 (12.82) & $02(5.55)$ & 이 (I.75) \\
\hline & $\mathrm{A}$ & & $10(25.64)$ & $06(16.66)$ & $03(5.26)$ \\
\hline IFSION TYPF & $\mathrm{BI}$ & & $13(33.33)$ & $18(50)$ & $13(22.8)$ \\
\hline LESION ITPE & B2 & & $10(25.64)$ & $05(13.88)$ & $21(36.84)$ \\
\hline & $\mathrm{Cl}$ & & $06(15.38)$ & $07(19.44)$ & $20(35.08)$ \\
\hline $\begin{array}{l}\text { angiographic morphologic } \\
\text { also more frequent. } \\
\text { predominance of locatio } \\
\text { in the ostial to proximal s } \\
\text { vessel. Severely occlusive } \\
\text { to } 99 \% \text { ) was found in } 59 \% \\
\text { of SVD, DVD and TV } \\
\text { While total occlusive } \\
\text { vessel with resultant } \\
\text { Thrombolysis in Myocar } \\
\text { (TIMI) flow has been fo } \\
\text { the total I } 32 \text { lesions (2 } \\
24 \% \text { of SVD, DVD and }\end{array}$ & $\begin{array}{l}\text { es were } \\
\text { was a } \\
\text { lesion } \\
\text { s of the } \\
\text { e } 70 \% \\
\text { nd } 25 \% \\
\text { ectively. } \\
\text { of the } \\
\text { zero } \\
\text { farction } \\
20 \% \text { of } \\
\% \text { and } \\
\text { respec- }\end{array}$ & $\begin{array}{l}\text { tively). Although defini } \\
\text { found in only } 6 \% \text { of th } \\
\text { be presumed that the } \\
\text { lesions associated } \\
\text { acute myocardial infar } \\
\text { thrombotic in origin. } \\
\text { morphology of the inc } \\
\text { concerned, most of t } \\
\text { concentric, discrete th } \\
\text { and located along stra } \\
\text { the vessels with little o } \\
\text { We also observed th } \\
\text { lesions were found to b }\end{array}$ & $\begin{array}{l}\text { thrombus was } \\
\text { esions, it could } \\
\text { tally occlusive } \\
\text { unheralded } \\
\text { on, were also } \\
\text { As far as the } \\
\text { dual lesions is } \\
\text { lesions were } \\
\text { ubular, simple } \\
\text { it segments of } \\
\text { o calcification. } \\
\text { I4\% of the } \\
\text { Type A, } 33 \%\end{array}$ & $\begin{array}{l}\text { of Type } \mathrm{BI}, 27 \% \\
\text { Type } \mathrm{Cl} \text { and non } \\
\text { implies that } \mathrm{PCl}, \mathrm{i} \\
\text { lesions, would car } \\
\text { rate with low risk } \mathrm{i} \\
\text { Type A and Type } \mathrm{E} \\
\text { while } 27 \% \text { (type } \\
\text { carry a moderate } \\
85 \% \text { with modera } \\
\text { (Type C) lesions (i. } \\
\text { the lesions), a lov } \\
<60 \% \text { would be } \\
\text { risks involved. }{ }^{19-23} \mathrm{~V}\end{array}$ & $\begin{array}{l}\text { Type B2, } 25 \% \text { of } \\
\text { of Type C2. This } \\
\text { performed in such } \\
\text { y a }>85 \% \text { success } \\
47 \% \text { lesions (both } \\
\text { I lesions together), } \\
\text { B2) lesions would } \\
\text { success rate of } 60- \\
\text { e risk, and in } 25 \% \\
\text { in one fourth of all } \\
\text { er success rate of } \\
\text { expected with high } \\
\text { hen the The Society }\end{array}$ \\
\hline
\end{tabular}


for Cardiovascular Angiography and Interventions (SCAI) lesion classification system ${ }^{24-27}$ is applied to the lesions in our study, where lesion patency carries more importance, it can be implied more than $20 \%$ of the lesions would be technically difficult lesions to handle carrying a higher risk and lower expected success rate.

The finding of less extensive coronary artery disease with more complex lesions observed in younger patients in our study might suggest that there is rapid disease progression (plaque rupture, plaque complication, or both) in younger population. This is in agreement with the finding that younger patients with coronary artery disease commonly present with an unheralded acute coronary syndrome without prior history of angina. ${ }^{28-29}$ In contrast; a contemporary study in the same setting compared the clinical and angiographic features of young versus older patients. They found no significant difference with respect to clinical features as well as lesion severity and occurrence of normal coronary arteries. However, lesser extensive coronary artery disease was met in younger group of patients. ${ }^{30}$

We, therefore, suggest coronary angiography along with urgency for early revascularization should be mandatory in patients who sustain acute $\mathrm{MI}$ in a younger age, even if asymptomatic with anti-ischemic medication.

\section{CONCLUSION}

This study shows that young (age $<35$ years) patients presented with acute myocardial infarction, have less extensive coronary artery disease but complex morphologic features. There was a higher incidence of normal vessels on coronary angiography with a very few cases of left main coronary arterial involvement.

\section{REFERENCES}

I. Hong MK, Cho SY, Hong BK, Chang $\mathrm{KJ}$, Mo-Chung I, Hyoung-Lee M, et al. Acute myocardial infarction in young adults. Yonsei Med J I 994 ; 35 (2): I 84 - 9. DOI: 10.3349/ymj. I 994.35.2.184

2. Fournier JA, Cabezon S, Cayuela A,
Ballesteros SM, Cortacero JA, Diaz De La Llera LS. Long-term prognosis of patients having acute myocardial infarction when $\leq 40$ years of age. Am J Cardiol 2004;94(8):989-92. DOI: |0.1016/j.amjcard.2004.06.05 |

3. Yusuf S, Hawken S, Ounpuu S, Dans T, Avezum A, Lanas F, et al. Effect of potentially modifiable risk factors associated with myocardial infarction in 52 countries (the INTERHEART study): Case-control study. Lancet 2004;364(9438):937-52. DOI: I0.1016/S0140-6736(04)।7018-9

4. Suresh G, Subramanyam K, Kudva S, Saya RP. Coronary artery disease in young adults: Angiographic study - A single center experience. Heart India 2016;4(4): I32-5.

5. Egred M, Viswanathan G, Davis GK Myocardial infarction in young adults. Postgrad Med J 2005; 8 I ( 962 ) : 74 I - 5 . D O I: I0.1 |36/pgmj.2004.027532

6. Bhatnagar D, Anand IS, Durrington PN, Patel DJ, Wander GS, Mackness $\mathrm{MI}$, et al. Coronary risk factors in people from Indian sub-continent living in West London and their siblings in India. Lancet 1995; 345(8947):405-9.

7. Enas EA, Mehta J. Malignant coronary artery disease in young Asian Indians: thoughts on pathogenesis, prevention and treatment. Clin Cardiol 1995; 18(3):131-5.

8. British Heart Foundation (BHF). coronary heart disease statistics 2003. [Cited on: March 28, 2017] Available from URL: http:// www.bhf.org.uk/ professionals/statistics

9. Ebbeling CB, Pawlak BB, Ludwig DS. Childhood obesity: public health crisis, common sense cure. Lancet 2002; 360(933I):473-82. DOI: I0.1016/S0I40-6736(02)09678-2

10. Horton R. Who pays in the obesity war? Lancet 2003;363(9406):339. DOI: $10.1016 / S 0140$. 6736(04)I5469-X

II. Alizadehasl A, Sepasi F, Toufan M. Risk factors, Clinical manifestations and Outcome of Acute Myocardial
Infarction in Young Patients. J Cardiovasc Thorac Res 2010;2 (I): 29-34.

12. Vivo RP, Krim SR. ST elevation myocardial infarction in a teenager: case report and review of the literature. South Med J 2009; I02(5):523-6. DOI: 10.1097/SMJ.0b0I3e31819984fc.

13. Tamrakar R, Bhatt YD, Kansakar S, Bhattarai M, Shaha KB, Tuladhar E, et al. Acute Myocardial Infarction in Young Adults: Study of Risk factors, Angiographic Features and Clinical Outcome. Nepalese Heart J 2013;10(1):12-6.

14. Jeffery JP. Coronary arteriography and intravascular imaging. In: Braunwald E, Libby P, Bonow RO, Mann DL, Zipes D editors. Braunwald's heart disease: A textbook of cardiovascular medicine. $8^{\text {th }}$ ed. Philadelphia, Pa: Saunders Elsevier; 2007: p.465-500.

15. Fournier JA, Sanchez A, Quero J, Fernandez-Cortacero JA, Gonzalez-Barrero A. Myocardial infarction in men aged 40 years or less; a prospective clinicalangiographic study. Clin Cardiol 1996; 19(8):631-6.

16. Teng JK, Lin LJ, Tsai LM, KwanCM, Cheng JH. Acute myocardial infarction in young and very old Chinese adults: Clinical characteristics and therapeutic implications. Int J Cardiol 1994; 44(I):29-36.

17. Negus BH, Willard JE, Glamann DB, Landau C, Snyder RW 2nd, Hillis D, et al. Coronary anatomy and prognosis of young asymptomatic survivors of myocardial infarction. Am J Med 1994;96(4):354-8.

18. Chen L, Chester M, Kaski JC. Clinical factors and angiographic features associated with premature coronary artery disease. Chest 1995; 108(2):364-9.

19. Ryan TJ, Faxon DP, Gunnar RM, Kennedy JW, King SB 3rd, Loop FD, et al. Guidelines for percutaneous coronary angioplasty. A report of the American Heart Association/ American College of Cardiology Task Force on Assessment of 
Diagnostic and Therapeutic Cardiovascular Procedures (Subcommittee on Percutaneous Transluminal Coronary Angioplasty). Circulation 1988;78(2):486-502.

20. Ellis SG, Vandormael MG, Cowley MJ, DiSciascio G, Deligonul U, Topol EJ, et al. Coronary morphologic and clinical determinants of procedural outcome with angioplasty for multivessel coronary disease. Implications for patient selection. Multivessel Angioplasty Prognosis Study Group. Circulation 1990;82(4): $1193-202$.

2I. Tan K, Sulke N, Taub N, Sowton E. Clinical and lesion morphological determinants of coronary angioplasty success and complications: Current experience. J Am Coll Cardiol 1995;25(4):855-65. DOI: 10.1016/0735-1097(94)00462-Y

22. Rosen AD, Detre KM, Alderman E, Stadius M, Sopko G. How reliable is the assessment of coronary angiography? Circulation 1993;88(4):653

23. Botas J, Stadius ML, Bourassa MG, Rosen AD, Schaff HV, Sopko G, et al, and the BARI investigators: Angiographic correlates of lesion relevance and suitability for percutaneous transluminal coronary angioplasty and coronary artery bypass grafting in the Bypass Angioplasty Revascularization Investigation study (BARI). Am J Cardiol 1996;77(10):805-I4.

24. Krone RJ, Laskey WK, Johnson C, Kimmel SE, Klein LW, Weiner BH, et al. A simplified lesion classification for predicting success and complications of coronary angioplasty. Registry Committee of the Society for Cardiac Angiography and Interventions. Am J Cardiol 2000;85(10): I I 79-84.

25. Krone RJ, Kimmel SE, Laskey WK, Klein LW, Schechtman KB, Cosentino JJ, et al. Evaluation of the Society for Coronary Angiography and Interventions' lesion classification system in 14,133 patients with percutaneous coronary interventions in the current stent era. Catheter Cardiovasc Interv 2002; 55(I): I-7.

26. Krone RJ, Shaw RE, Klein LW, Block PC, Anderson HV, Weintraub WS, et al. Evaluation of the American College of Cardiology/ American Heart Association and the Society for Coronary Angiography and Interventions Lesion Classification System in the Current "Stent Era" of Coronary Interventions (from the
ACC-National Cardiovascular Data Registry). Am J Cardiol 2003;92(4):389-94.

27. Krone RJ, Shaw RE, Anderson HV, Block PC, Brindis RG, on behalf of the ACC-NCDR. Outcome of PCl with stenting is independent of lesion classification, but lesion classification by the ACC or SCAI system assumes great importance if a stent is not used. A report from the ACC-National Cardiovascular Data Registry (ACC-NCDR). J Am Coll Cardiol 2002; 39: 1096-103.

28. Klein LW, Agarwal JB, Herlich MB, Leary TM, Helfant RH. Prognosis of symptomatic coronary artery disease in young adults aged 40 years or less. Am J Cardiol | 987;60(I6): | 269-72.

29. Kanitz MG, Giovannucci SI, Jones JS, Mott M. Myocardial infarction in young adults: Risk factors and clinical features. J Emerg Med 1996; 14(2): | 39-45.

30. Shah SS, Noor L, Shah SH, Sawar S, Din SU, Awan ZA, et al. Myocardial infarction in young versus older adults: clinical characteristics and angiographic features. J Ayub Med Coll Abbottabad 20 I 0;22(2): I87-90.

\section{AUTHOR'S CONTRIBUTION}

Following authors have made substantial contributions to the manuscript as under:

LN: Study design, acquisition, analysis \& interpretation of data, drafting the manuscript, final approval of the version to be published

YA, MHD, UA, FA: Acquisition of data, drafting the manuscript, critical revision, final approval of the version to be published

ZAA: Concept, acquisition of data, critical review, final approval of the version to be published

Authors agree to be accountable for all aspects of the work in ensuring that questions related to the accuracy or integrity of any part of the work are appropriately investigated and resolved.

\begin{tabular}{|c|} 
CONFLICT OF INTEREST \\
Authors declared no conflict of interest \\
GRANT SUPPORT AND FINANCIAL DISCLOSURE \\
NIL
\end{tabular}

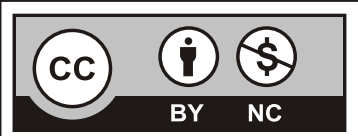

This is an Open Access article distributed under the terms of the Creative Commons Attribution-NonCommercial 2.0 Generic License. 